\title{
GREEN ECONOMY AND ACCESS TO FINANCE IN GEORGIA (GOING BEYOND THE COMMERCIAL BANKING SECTOR TO FINANCE BUSINESSES IN GEORGIA)
}

\section{DAVID ASLANISHVILI}

\author{
PHD, Professor
}

Caucasus University, Georgia

daslanishvili@cu.edu.ge

KEYWORDS: GREEN ECONOMY, ACCESS TO FINANCE IN GEORGIA.

For citation: Aslanishvili D. (2019), Green Economy And Access To Finance In Georgia (Going Beyond The Commercial Banking Sector To Finance Businesses In Georgia), Globalization And Business, №7, pp. 87-95. https://doi.org/10.35945/gb.2019.07.011

\section{GREEN ECONOMY AND ACCESS TO FINANCE IN GEORGIA (GOING BEYOND THE COMMERCIAL BANKING SECTOR TO FINANCE BUSINESSES IN GEORGIA)}

\subsection{Green Bonds - International Practice}

Huge efforts and financial resources are needed to ensure sustainable development and achieve climate and environmental objectives. It is estimated that total global investment needs are around USD 5-7 trillion per year. In particular, support of private finance is needed, with public finance serving to leverage such private capital. (Future we want. 2912. Outcome document of the United Nations Conference)

As a result of the analysis of the World Economic Forum, it is necessary to invest about $\$ 5.7$ trillion in the Green Economy every year, from which 5 trillion funding should be directed directly to green infrastructure and business projects, and the remaining 700 billion will be able to effectively manage these projects.

A large number of financial instruments can also be applied by the government to support the scaling-up of green investments. These include, among others;

- instruments that provide direct financing from the budget (at the national and sub-national level), such as equity, grants, government soft loans;

- instruments that mitigate risks (e.g. guarantees, feed-in tariffs);

- instruments that help raise additional private funds (e.g. green bonds) (Lindenberg, N., 2014).
The concept of green bonds was launched almost 10 years ago, by leading development finance organizations such as the World Bank, the IFC and the EIB, together with pioneering investment banks. In little more than a decade, annual green bond issuance has grown from zero to nearly $\$ 170 \mathrm{bn}$.

- In 2019, global issuance is expected to reach a record $\$ 200 \mathrm{bn}$. That growth is impressive - and a measure of investors' eagerness to address the greatest development challenge of our time.

- Yet green bonds remain a small sliver of the \$100tn global bond market.

- In 2016, the Swedish Pension Fund (AP4) allocated $21.8 \%$ of its global equity portfolio to low-carbon projects.

- AP4 aims to decarbonize its entire global equity portfolio by 2020 .

- Similar initiatives are taking place in other OECD countries as well (e.g. the Portfolio DE carbonization Coalition in the USA embracing 28 institutional investors have pledged to gradually decarbonize a total of USD 600 billion by designing investment portfolios with a smaller climate change impact).

- Currently, Europe is leading the green bond market, with numerous Europe-based mutual funds focusing on green bonds. The EU is in the process of boosting the market for green bonds for infrastructure and SMEs.

- Despite previous experience of some countries in the region with municipal bonds for water supply and sanitation infrastructure (e.g. Ukraine, Kazakhstan) none of the EaP countries and Central Asia seems to have issued green bonds so far to finance low-carbon investments. 
- However, Ukraine is considering the creation of a green bond market and have prepared "Green Bond Guidelines: Roadmap for Ukraine". The introduction of green bonds is also being considered in Kazakhstan.

In the majority of developed countries, many specialized financial institutions that support green investment and support of energy efficient projects in developing countries, including Georgia, have been created to support green projects. One of the examples is the European «Green Growth Fund», which implements energy in the energy industry and reduces greenhouse gas emissions in up to 20 developing economies.

The foundation was founded in Luxembourg in 2009 by the Development Bank of Germany and the European Investment Bank, which has financial support from other leading international financial institutions such as the Austrian Development Bank, the European Bank for Reconstruction and Development Bank, the International Finance Corporation, the Dutch Development Bank, etc.

The EU funded the new multinational program in the context of the Eastern Partnership (EU for Environment), which was implemented in Georgia in April 2019.

The EU4ENVRM program aims at helping EU partner countries to maintain and utilize their natural capital to boost the ecological well-being of the population and use new opportunities for development. For instance, enterprises (particularly small and medium sizes) will receive further assistance in terms of saving energy, water and materials: leading international experts will consult environmental management.

This new program will support Georgiass efforts to improve the challenges in the development of green economy development. For all 6 countries of the Eastern Partnership, this program has a total of 20 million euros. The results of the work carried out by the EU and local institutions are that within the 2019 exhibition Georgian companies have received more than 600000 Euros order from international buyers.

\subsection{Links between economic growth, green growth (e.g. clean energy), high living standards and capital markets "Green" economy}

The Rio Conference in June 2012 reflected a trend that focuses on the economic system. Term "green" economy was first used in 2013. The concept of green economy is transferred in the document of Rio de Janeiro conference dedicated to the sustainable development "future we want". As United Nations Environment Program (UNEP) defines "green" Economy is an economy that provides growth of peopless well-being in the long term and reduces inequalities in order to enable future generations to avoid environmental and its impoverishment risks.

The main focus in the definition on the growth of peopless welfare, because nature conservation, protection and in some cases, improvement by itself serves to increase peopless wellbeing. To be more specific a "green" economy means ecological needs' that have been improving the social and economic situation of people through the rational use of resources, the preservation of the process of nature reproduction, ensuring the safety of living organisms and the growth of production.

"Green" economy goals also serve to provide resources for the future, due to the fact that non-renewable, exhausted resources will be replaced by renewable, environmentally friendly resources. Although the problem of providing resources in the future is much huger and global. The main sectors of the green economy are:

- Renewable energy (solar, wind, geothermal, marine, including waves, biogas and heat energy);

- Green buildings (green modifiers, green products and materials);

- Clean Transport (Alternative Fuel, Public Transport, Hybrid and Electric Vehicle);

- Water management (water and rain treatment systems, internal water landscape, water usage);

- Waste management (utilization, municipal waste, use of materials, soil fertility improvement, cleaning);

- Land management (organic agriculture, urban forests and parks, forest development)

\section{«Green» Economy in Georgia}

«Georgia-EU Association Agreement» focuses on sustainable development and green economy. In particular, Article 301 of the Agreement states that «the Parties will develop and strengthen cooperation on environmental issues, thus contributing to sustainable development and long-term goals of the green economy.

Tbilisi City Hall is particularly active in the direction of a "green economy "that developed the Environmental Strategy on 2015-2020 and Green City Action Plan for 2017-2030.

According to the 2018 Global Green Economy Index (GGEI), Georgia is taking an intermediate position among world countries. On the other hand, according to the Environmental Performance Index (EPI), Georgia meets only in the second half of the world, but with improved indicators. Georgia is rich in natural resources and has the potential for rapid development.

The richness of Georgia has the potential for rapid development of natural resources. There are certain ways for developing countries to achieve global green growth. In many countries the green growth is understood as an inclusive economic development, which envisages the development and maintenance of environmental and social values.

According to the data of 2018, Georgia occupies the 44th place among 130 countries $(0,5183)$. And the first five looks as follows:

- Sweden 0.7608

- Switzerland 0.7594 
- Iceland 0.7129

- Norway 0.7031

- Finland 0.6997

The last places were distributed: Guinea-Bissau, BosniaHerzegovina, Benin, Haiti, Bahrain.

According to the data of 2018, Georgia ranked 94th in the ecological efficiency rating among 180 countries compared to 2016 (111th place), improved by 17 points. In total, Georgia received 55.69 points from 100 points (2018).Among the neighbors is the best situation in Russia - 63.79 points (52nd place), Azerbaijan - 62.33 points (59th place), Armenia - 62,07 points (63rd place). It is noteworthy that in 2016 this situation worsened in Turkey (108) and Ukraine (109th place).

\subsection{Green Tourism As An Important Component Of The Transition To A Green Economy And Economic Growth}

In the mid-2000 the tourism industry accounted for 5\% of global GDP and provided about $8 \%$ of total employment. This industry ranked fourth in world exports (after the fuel, chemical and automotive industries). Since tourism is playing an important role in economy, a green tourism is a considerable component of the transition to a green economy. Thus, all types of tourism should become green and sustainable, namely:

- make optimal use of environmental resources, which are a key element for the development of tourism, support key environmental processes and promote the conservation of natural resources and biodiversity;

- respect the sociocultural identification of local communities, help preserve their cultural heritage and traditional values;

- to ensure sustainable long-term economic activities that provide socioeconomic equitable benefits for all parties involved, including tourist satisfaction, stable employment and income-generating opportunities, and social services to host communities.

\section{Georgian non - traditional funding (Capital Market in Georgia)}

What is the present and the future for the stock and debt capital market in Georgia?

Here we have studied possible financial vehicles that go beyond traditional sources of private capital offered by commercial banks.

\subsection{Georgian Capital Market - On-going trends and development Problem Statement}

The mission of research proposal is to find out the real solution to rapidly develop countries like Georgia based on modern capital market tools. Economic progress and improving living standards of the population depends largely on the provision of high economic growth. That issue itself heavily depends on energy sources and mostly on green sources.

To attract capital into green energy objects, it is obligatory to have reliable and strong market foundation and its tools. One of the real levers, and the most acceptable and practical forms of investment are to invest in equities through the stock market. It is clear for the developed world how important the organized stock market is. This includes Western Europe, USA, Canada, Japan, China and other countries with powerful stock industries such as the New York Stock Exchange; Euronext; NASDAQ OMX; the London Stock Exchange and many others.

The mediation business or brokerage/investment firms include Merrill Lynch; Morgan Stanley; Goldman Sachs; J.P. Morgan; Barclays Capital and many other investment banks.

Georgian corporate bonds eligible in Clearstream from September 2018. Clearstream Banking S.A. started offering settlement, custody and asset servicing for selected Georgian corporate bonds, which is in addition to the securities issued by the Government of Georgia and international financial institutions (the "IFIs"). By offering new services in Georgia, Clearstream further enhances the access to the Georgian capital market for international investors and is the sole international central securities depository (the "ICSD") to offer such services. Non-resident corporate, non-resident individual and resident individual holders of Georgian listed corporate bonds issued prior to 2023 are exempt from capital gain and interest income (withholding) taxes.

MORE THAN 2 BILLION GEL SUCCESSFUL PLACEMENTS OF IPO DONE in Georgia during the last five years:

- FMO (Nederlandse Financierings-Maatschappij voor Ontwikkelingslanden N.V)

- Black Sea Trade and Development Bank

- Bank of Georgia

- Liberty Bank

- M2 Real Estate

- TBC BANK

- EBRD bonds

- ADB bonds

- Georgian Leasing Company

- Nikora

- Zedazeni

- EVEX

- GWP (Georgian Water and Power)

- Lisi Lake

- Teliani Wine

- Silknet

- Microfiance Organisation Crystal

(source: www.gse.ge)

June 28, 2019 Tbilisi, Georgia: TBC Capital has listed the largest Eurobond issue on the Georgian Stock Exchange. TBC 
Bank has successfully priced a debut US\$300 million 5-year $5.75 \%$ ( $6 \%$ yield to maturity) senior unsecured notes issue (the "Notes").

July 12, 2019 - The Asian Development Bank (ADB) raised 60 million GEL (about $\$ 21 \mathrm{~m} / € 18.70 \mathrm{~m}$ ) from two new issues of local currency bonds. The proceeds of the bond issues will be on-lent to Credo Bank to launch new products including home improvement and mortgage loans to lower income households in rural areas and on the outskirts of Georgian capital, Tbilisi.

TEGETA MOTORS LTD - On May 22, 2019, GEL 30 million worth of 3-year bonds issued by the Tegeta Motors LTD have been admitted to the category $A$ listing of the Georgian Stock Exchange.

Research has ascertained that Georgia faces the problem between the two basic means of attracting monetary resources -Commercial Bank lending/loans and the stock market. In financially successful and developed countries, these two mechanisms-bank loans and the stock market-are designed to attract money and create a mutually beneficial synergy. In Georgia, there is only one mechanism to attract money resources -the bank loan.

In general, the Georgian commercial banking system tries its utmost to prevent the use of the second mechanism, the stock market, since it is considered a main competitor. The analysis of the structure of owners of Georgian Stock Exchange (source: securities registrar JSC Kavkasreestri www.kavkasreestri.ge) shows that $58 \%$ of shares of the stock exchange is in hands of its competitor - Georgian commercial banks/holdings. ((D Aslanishvili (2016) Market Foundation...)

There is another stock exchange - Tbilisi Stock Exchange, where owners are just commercial banks/holdings and Georgian Stock Exchange as minority shareholder itself (fully under control of Commercial Banks/holdings).

It means that Georgian commercial banks will not allow the development of their competitor-the stock market--as it threatens their own preferential and successful financial position.

According to this analysis, Commercial banking and Stock Market have one mega regulator - the National Bank of Georgia. It should be noted, that an essential attribute of the stock market - the National Securities Commission of Georgia (NSCG) - was abolished. The power of the NSCG was transferred to the regulator of Georgian commercial banks and lobbyist of their interests - the National Bank of Georgia.

Simultaneously, very tough policies were enacted against non-commercial banking structures - brokerage firms, registrar companies and market participants. As the result-there are practically no non-commercial banking funding ability to attract finance in Georgia.

Fixation rule - unfortunately, there is no public trades and market price on Stock Exchange. Securities admitted to the stock exchange can be transferred by simple inscription on paper, without any auction or trading - it is enough simply to sign the paper document. ( (D Aslanishvili (2016) Market Foundation...)
As the analysis shows, the management of joint stock companies (non-commercial banks) gradually lost any interest in equity trading in an open and transparent environment, once the law didn't require it. As the results - there is no de facto market price on any stock on Georgian Stock Exchange

- BROKERAGE FIRMS

- Galt \& Taggart JSC

- Caucasus Capital Group JSC

- $\quad$ Silk Road Bank JSC

- Heritage Securities JSC

- TBC Capital Ltd

- Cartu Broker LTD

(source: www.gse.ge)

Is there ANY real positive trend? - STOCK MARKET

In 2013, the country's stock exchange turnover amounted to GEL 530,491 or 338-fold less compared to 2007

In the period from January 1, 2014 - July 14, 2019

Number of Trades - 667

Volume - 32,666,230

Total Value (GEL) - 2,770,069.42

(www.gse.ge)

At average per year - 461,678 Georgian Lari turnover Approximately all trades go on Banking stocks and affiliated companies

Is there ANY real positive trend? - BOND MARKET

In the period from January 1, 2014 - July 14, 2019 :

Number of Trades - 140

Volume - 13,243

Total Value (USD) - 13,810,688.40

At average per year - 2,301,781 USD turnover Approximately all trades go on Banking Bonds and affiliated companies

\subsection{So, Where Is The Turnover And Market?}

\section{GRAY MARKET (OTC MARKET)}

In the period from January 1, 2014 - July 14, 2019:

Number of Trades - 2,319

Volume - 6,031,596,962

Total Value (GEL) - 2,323,956,196.85

At average per year - 38,732,603 GEL turnover - Mostly turnover goes on Banking Stocks/Bonds and affiliated companies. 
Presently, Georgia's stock exchange has lost its key function as a foundation for price formation in the stock market. Therefore, any trading in shares or other securities publicly has become senseless.

Fixation of Deals out of Market (gray Market, OTC) represent the only way of funds attraction. As practice shows, Commercial Banks distribute the adopted offer of stocks/ bonds inside the banking/holding structure for own clients and submit the fulfilled IPO to Stock Exchange. Stock Exchange act as Notary, but not as Stock Exchange.

Any suggestion on legislative amendments as a solution in order to save and develop independent from Commercial bank's Georgia's stock exchange had been many times stopped and blocked by Georgian government, National Bank and Commercial Banks, working together to keep the current trend. ((D Aslanishvili (2016) Market Foundation...)

The only way to get finance in Georgia is to be loyal to Commercial Banks and its affiliated structure(s) and show the readiness to give them access to your company share structure and management to receive funding.

\section{3 “THE ROAD TO HELL IS PAVED WITH GOOD INTENTIONS"}

So the reality is simple:

MANY TALKS OF SECURITIES MARKET, ALTERNATIVE SOURCE OF COMMERCIAL BANK LENDING, IPO AND STOCK MARKET DEVELOPMENT, BUT REALITY IS OPPOSITE....

Georgia needs the REAL Glass Steagal/Dodd-Frank Act in action, not in paper.

\section{Situation in Summary}

- Commercial Banks/Holdings fully control non-commercial source of funding - "Georgian Stock Exchange"- 58 percent of Stake of GSE and 100 percent control of "Tbilisi Stock Exchange";

- Supervisory Board and Management of Stock Exchange in hands of Commercial Banks/holdings;

- Commercial Banks and its affiliated structure mostly prefer to have IPO and trades OUT OF GEORGIA and its Stock Market (London Stock Exchange);

- Registrars (Transfer Agents) - the most developed are in hands of Commercial banks/holdings;

- Licensed by NBG and GSE Brokerage Companies almost all in property of Commercial Banks/holdings;

- All emissions and successful placements of companies (Bonds/stocks) are done only by Commercial Banks and for their and affiliated companies;

- THERE IS NO ALTERNATIVE SOURCES OF FUNDING IN GEORGIA EXCEPT COMMERCIAL BANK LOAN DIRECTLY OR INDIRECTLY (via their "green light" to issue bonds/stocks for Banks of affiliated companies).

\section{SOLUTION}

- Georgia needs the REAL Glass Steagal/Dodd-Frank/The Gramm-Leach-Bliley Acts in action, not JUST in paper.

- We need independent from Commercial Bank/Holdings the Supervisor and Stock Market structure

- Commercial Banks/Holding should be prohibited from Stock Market activity.

\section{CONCLUSION}

- Main sources of funding for SME green investments in Georgia are Commercial Banks and affiliated structures;

- Capital market - stock and bond markets in Georgiais not developed as alternative source of funding for any noncommercial banking structure;

- There is a lot of real benefits of non-bank financing, including for clean energy projects and the SME sector (e.g. small hydro, energy efficiency);

- Government can use State Bonds/obligations, its affiliated structures (Partnership fund) to support SME finance in green economy;

- Government of Georgia should intervene and change the "rule of games" on Capital market and to introduce the REAL Glass Steagal/Dodd-Frank/The Gramm-Leach-Bliley Acts in action, not JUST in papers;

- Georgia needs an independent from Commercial Bank/ Holdings and National Bank of Georgia the Supervisor and Stock Market structure - to have the Real alternative source of funding;

- Commercial Banks/Holding should be prohibited from Stock Market activity (depositors risk mitigation - international practice);

- International community (donors, IFIs, international organization) should supervise the REAL implementation of abovementioned steps in Georgian reality to support Georgia's efforts to have the Real developed capital markets, available to finance business.

\section{POSSIBLE INVESTMENTS IN CLEAN ENERGY PROJECTS OF GEORGIA (E.G. SMALL HYDRO, ENERGY EFFICIENCY)}

Georgia has the greatest potential to become an important exporter of electricity received from renewable energy transformation. This gives our country a significant advantage in the entire region. This advantage can be considered as two important aspects:

- Energy independence, which is of paramount importance to maintain political stability in the region,

- Economic benefits, after fully satisfying domestic consumption, export of electricity to neighboring countries.

The first place among the natural riches of Georgia is the 
hydro-electrical. There are 26060 rivers on the territory of Georgia, with total length of approximately 60 thousand km. The common stock of fresh water of Georgia, comprising 96,5 $\mathrm{km} 3$ of glaciers, lakes and reservoirs of water reserves.

From the total number of rivers, there are about 300 rivers with energy value, the annual total potential capacity of 15 thousand megawatts and average annual energy equivalent to 50 billion kWh. Georgia is a wealthy country with renewable energy resources, but it is a poor source of energy sources.

In 2016, 57.6 thousand terrestrial power plants were produced in Georgia, which is 1.4 million tons of oil equivalent. More than half of this energy was on hydropower resources - $58.3 \%$. $28.2 \%$ of the biofuels and waste are still large in the energy produced. The remaining energy sources have a relatively small share of domestic production: coal $-8.7 \%$, crude oil - $2.8 \%$, geothermal $-1.5 \%$, gas $-0.4 \%$

Energy consumed in Georgia is 3.15 times higher than the energy required, which is largely due to demand for nonrenewable energy resources, which is not available in the country, but traditional energy resources are widely used in a number of fields.

As a result, in 2016, almost one-third of the countryss domestic consumption of petroleum products $(33.1 \%)$ and slightly less natural gas (30.5\%).

In the world as well as in Georgia, the role of coal is reduced in the economy (5.8\% of consumption). $20.8 \%$ of the domestic consumption comes from electricity, the source of which is the renewable energy/ unprofitable energy or import of the internal one. Only $0.4 \%$ of domestic internal consumption comes from geothermal energy. Over the next 10 years, new electric power capacity is expected to turn Georgia into an important exporter of electricity.

With realistic calculations, electricity consumption in Georgia will increase by 3.5\% per annum in the following years. As a result, net exports of 9.9 billion kWh electricity will be expected by 2027 , which will be $37.6 \%$ of the total electricity generated.

The list of potential projects is drawn up by the Ministry of Energy of Georgia for the potential investors (Order N125/) on Approving List of Potential Power Plants in Georgia (available to show). For each project, the average annual output is given. Some assumptions are used to calculate the value added by them (assumptions are taken from potential projects).

- Export tariff - 0,080

- Internal supply tariff - 0,048

- Technical losses and their own consumption - 3\%

- Export Share - 80\%

- Share of internal supply - $20 \%$

The following assumptions are used:
- Average Annual Production of Each Project Decreases Technical Losses (0.03\%);

- The derivative output is divided between export and internal supply $(80 \%-20 \%)$;

- The derivatives generated are multiplied by the cost of electric power of Kilowatt and the sum;

- The final added value is divided on macroeconomic indicators to assess its share.

- The macroeconomic indicators used the GDP of 2017 at current prices (15,230 billion USD) and the export indicator of 2017 (2,348 billion USD).

Following the aggregation of the information received at the project level, it is possible to see the general picture, first of all, to project projects according to their status:

- Construction and Licensing Projects (45 projects) After completion of full exploitation, they will generate a total additional cost of $2.5 \%$ of current GDP (2017).

- The second group consists of research projects under construction commitment (22 projects), the potential share of which is $2.2 \%$ of the current GDP. These are the projects for which the terms and obligations of construction are determined, but research works are still under way.

- The next group is the projects at the stage of technical and economic research ( 80 projects). There is an expressed interest in these projects by investors, although only research works are underway, after which the terms of their construction may be determined. The total contribution of these projects to GDP is $4.6 \%$.

- The fourth group is potential projects (99 projects), which are only theoretical and the investoris interest is not expressed. The potential share of potential projects in GDP is $3.2 \%$.

- Renewable energy current and potential projects are determined by several renewable energy sources. As mentioned above, hydropower has a vital role in the Georgian energy sector.

- The total potential contribution of hydro power plants (both ongoing and potential) to the current economy is quite high and $10.2 \%$.

- After hydropower, Georgia is attractive for investors with wind energy, which is $2.0 \%$ for wind power plants.

- Interest in the use of solar energy is scarce $(0.3 \%)$, as well as bio waste recycling.

- Overall, the potential contribution of all four types of projects in the economy is $12.6 \%$, which is quite high.

Obviously the research is based on certain assumptions, and all project implementation will require tens of years, and with the growth of the current economy, their contribution to economic growth in other equal conditions will be reduced. However, potential economic benefits of projects are more visible. 


\section{REFERENCES:}

1. Davit Aslanishvili, (2019). International Conference on: Cooperation, Development, Exchange in Higher Education: Academic practices and achievements from Emerging Europe, Hungary, Miskolc University, May 7, 2019;

2. D Aslanishvili (2016) Market Foundation for Sustainable Economy Growth and Energy Policy (Georgian Case). Modern Economy, volume 7, p. 314 -319Modern Economy, 2016, 7, 314-319 Published Online March 2016 in SciRes. http://www. scirp.org/journal/me, http://dx.doi.org/10.4236/me.2016.73034

3. Aslanishvili, D. and Omadze, K. (2016) Origins and the Reasons of Monetary Crises in Georgia (1995-2016). Modern Economy7, p. 1232-1250.http://dx.doi.org/10.4236/me.2016.711119

4. Aslanishvili, David; Muller, Dietrich; Omadze, Kristine, Analyse of the past Industrial Revolutions and possible outcome of the coming new fourth In-dustrial Revolution (Industry 4.0), Con-ference: International Scientific-Practical Conference Dedicated to the Foundation of the Institute Innova-tive Economy and Problems of Its Formation in Post-Communist Countries. Pages: 100-106, Year: 2016

5. Aslanishvili, David; Omadze, Kristine, Monetary Crises in Georgia - 1995 - 2016 Source: Ekonomisti, Volume: 8, Issue: 1, Pages: 89-108, Published: 2016

6. Aslanishvili, David, Ricardo equivalent, the origin of state debt, its meaning and practical purpose Conference: Modern Tendencies of Development of Economy and Economic Science, Pages: 18-22, Year: 2018

7. Aslanishvili, David; Omadze, Kristine, Georgiass external debt structure and the challenges of the current situation Conference: International Scientific Conference Dedicated to the 65th birth anniversary of Professor George Tsereteli Structural and Innovative Problems of Economic Development, Pages: 25-28, Year: 23-24 June, 2017,

8. Author(s): Aslanishvili, David; Omadze, Kristine, International Discussions on Bank Credit and Economic Growth Relationship (Expanded Summary), Source: Ekonomisti, Issue: 2, Pages: 62-74, Published: 2018

9. Aslanishvili, David, Place and importance of the government securities market in the European Union: recent trends and discussions (Expanded Summary), Source: International Scien-tific-Analytical Journal EKONOMISTI, Issue: 5, Pages: 12-14, Published: 2015

10. United Nations Environment Programme and World Tourism Organization (2012). Tourism in the Green Economy-Background Report, UNWTO, Madrid. [ Electronic resource]: Retrieved from https://www.e-unwto.org/doi/pdf/10.18111/9789284414529 11. World Wide Fund For Nature (WWF, 2019). Over $80 \%$ of marine pollution comes from land-based activities. [Electronic resource]: Retrieved from http://wwf.panda.org/our_work/oceans/problems/pollution/

12. Future we want. 2012. Outcome document of the United Nations Conference on Sustainable. Development Rio de Janeiro, Brazil, 20-22 June 2012 https://sustainabledevelopment.un.org/content/documents/733FutureWeWant.pdf

13. Towards Green Growth. 2011. https://www.oecd.org/greengrowth/48012345.pdf

14. Berger, Roland. 2011. Green Growth, Green Profit How Green Transformation Boosts Business. Green Growth, Green Profit. US, New York: Palgrave Macmillan. https://doi.org/10.1057/9780230303874.

15. Cereceda Rafael, Cuddy Alice. 2018. "9 Out of 10 People Worldwide Breathing Polluted Air." Euro News. https://www. euronews.com/2018/05/02/9-out-of-10-people-breathing-polluted-air-worldwide.

16. Madhipatla, Kishore, S Venkatesh, D J Christopher, Jeffrey D Stanaway, R S Dhaliwal, LalitDandona, Virendra Singh, et al. 2018. "The Impact of Air Pollution on Deaths, Disease Burden, and Life Expectancy across the States of India: The Global Burden of Disease Study 2017." The Lancet PlanetaryHealth 3 (1): e26-39. https://doi.org/10.1016/s2542-5196( 18)30261-4. 17. World Health Organization. 2018. "World Health Organization Releases New Global Air Pollution Data." CCAC Secretariat. http:// ccacoalition.org/en /news/world-health-organization-releases-new-global-air-pollution-data. https://www.energy-community.org/ 18. A strategy for smart, sustainable and inclusive growth" and in 2011 "A resource-efficient Europe - Flagship initiative under the Europe 2020 Strategy"

19. Geoffrey Heal - THE ECONOMICS OF RENEWABLE ENERGY (2009)

20. International Energy Agency - World Energy Outlook 2016

21. Nicholas Apergisa, James E. Payneb - Renewable energy consumption and economic growth: Evi-dence from a panel of OECD countries (2010)

22. OECD (2009), "The Bioeconomy to 2030. Designing a p olicy agenda"; EU (2012), "Innovating for Sustainable Growth: A Bioeconomy for Europe"; U SA (2012), "National Bioeconomy Blueprint

23. TheEuropean Commission's 'Europe 2020' strategy con siders developing a smarter and greener Europe essential

24. Green for Growth Fund. www.ggf.lu

25. United Nations Framework Convention on Climate Change. www.unfccc.int

26. World Resources Institute. http://www.wri.org/our-work/project/climate-finance/climate-finance-and-private-sector

27. https://tradingeconomics.com/switzerland/gdp-per-capita

28. https://tradingeconomics.com/poland/gdp-per-capita

29. https://tradingeconomics.com/hungary/gdp-per-capita

30. https://tradingeconomics.com/georgia/gdp-per-capita

31. www.geostat.ge 


\title{
GREEN ECONOMY AND ACCESS TO FINANCE IN GEORGIA (GOING BEYOND THE COMMERCIAL BANKING SECTOR TO FINANCE BUSINESSES IN GEORGIA)
}

\section{DAVID ASLANISHVILI}

\author{
PHD, Professor
}

Caucasus University, Georgia

daslanishvili@cu.edu.ge

KEYWORDS: GREEN ECONOMY, ACCESS TO FINANCE IN GEORGIA.

For citation: Aslanishvili D. (2019), Green Economy And Access To Finance In Georgia (Going Beyond The Commercial Banking Sector To Finance Businesses In Georgia), Globalization And Business, №7, pp. 87-95. https://doi.org/10.35945/gb.2019.07.011

\section{SUMMARY}

This research will explore other possible financial vehicles that go beyond traditional sources of private capital offered by commercial banks. It will look at international experience and the opportunities to use public support, green bonds to raise green finance as well as the work of energy service companies (ESCOs) to finance green investments.

We have offered our view of what should be done in fact (not in paper in Georgia as it has been in the past 15 years) to change the situation and end the negative and harmful monopoly of the commercial banks and the National Bank of Georgia and to have in place the two independent sources to attract and invest resources in Georgia.

This will increase the capitalization of the country and is a proven way to eradicate the countrys lagging and accelerate economic growth.

Why should we focus on this issue?

1. According to WHOs latest data, over 7 million people die each year because of breathing air with solid particles, and one of its main pollutants is vehicles. (Cereceda Rafael, Cuddy Alice. 2018.....)

2. Georgia's Capital - Tbilisi - is occupying the 3rd place in the light of air pollution,

3. Due to the critical situation, the public demand to live in a clean ecological environment, day by day increases.
In our research the following Questions are discussed and overviewed:

- Is it important to act on the issues of Georgiass position on the global scale?

- What unique components can be used to prolong the average life of people?

- What investors do the country need for building ecoprojects and their realization?

- What type of ecofriendly technologies can be developed for potential customers in Georgia?

In that field we have studied the following:

- The links between economic growth, green growth (e.g. clean energy), high living standards and capital markets;

- Why the Commercial Banks are the main and the only source of finance for green (and not only) investments in Georgia;

- Situation on capital markets of Georgia (stock and bond markets) - as an indicator of economic growth and an alternative source of financing;

- Possible benefits of non-bank financing, including for clean energy projects and the SME sector (e.g. small hydro, energy efficiency);

- The role of government in supporting capital market development;

- The role of international community (donors, IFIs, international organization) to support Georgia's efforts to develop capital markets 


\section{Georgia - Recent level of development}

To illustrate the wide gap between the developed economy and the weak one, let us compare the current level of per capita GDP of Switzerland, Hungary, Poland to Georgian one (source: https://tradingeconomics.com/switzerland/gdpper-capita; https://tradingeconomics.com/poland/gdp-percapita; https://tradingeconomics.com/hungary/gdp-per-capita; https://tradingeconomics.com/georgia/gdp-per-capita);

- The Gross Domestic Product per capita in Switzerland was last recorded at 76667.44 US dollars in 2017. The GDP per Capita in Switzerland is equivalent to 607 percent of the worldıs average.

- The Gross Domestic Product per capita in Hungary was last recorded at 15647.85 US dollars in 2017. The GDP per Capita in Hungary is equivalent to 124 percent of the world ss average.

- The Gross Domestic Product per capita in Poland was last recorded at 15751.23 US dollars in 2017. The GDP per Capita in Poland is equivalent to 125 percent of the world ss average.

- The Gross Domestic Product per capita in Georgia was last recorded at 4290.17 US dollars in 2017). The GDP per Capita in Georgia is equivalent to 34 percent of the worldıs average. 